shipped out of the State of Pennsylvania eighteen cents per hour; (e) with requiring ( $\mathrm{I}$ ) sewing machine operators and (2) stenographers engaged in producing goods shipped out of the State of Pennsylvania to work fifty-four hours per week without compensation for overtime.

In his demurrer to the indictment appellee contended that the provisions of the statute upon which the indictment was based were unconstitutional as applied to him in that they (I) did not come within the commerce power of Congress; (2) violated the Tenth Amendment; and (3) deprived him of liberty and property in contravention of the due process clause of the Fifth Amendment. The District Court sustained the demurrer on each of the above grounds.

\title{
(A) AN OPINION HOLDING THE ACT CONSTITUTIONAL
}

\author{
ROBERT L. STERN*
}

\section{The Validity of the Act under the Commerce Claudse}

(a) Sections $15(a)(I)$ and (4). These subsections of Section 15(a) prohibit interstate sales and shipments of goods produced by oppressive child labor or by labor employed at less than the minimum wage or for more than the maximum hours. Such sales and shipments are, of course, interstate commerce. The prohibition of such sales and shipments is on its face a regulation of interstate commerce. Mulford $v$. Smith, 59 Sup. Ct. 648 (1939).

That Congress may under the commerce clause prohibit interstate commerce has been recognized in numerous decisions of this Court. Mulford v. Smith, supra; Champion v. Ames, I88 U. S. 321 (I903); Hipolite Egg Co. v. United States, 220 U.S. 45 (IgII); Hoke v. United States, 227 U. S. 308 (I9I3); Brooks v. United States, 267 U. S. 432 (I925); Gooch v. United States, 297 U. S. I24 (I936)..$^{*}$ It is equally clear that the power to prohibit interstate commerce includes the power partially to restrain such commerce, or to impose conditions upon the privilege of engaging in it. Mulford v. Smith supra; Currin v. Wallace, 59 Sup. Ct. 379 (I939); United States v. Rock Royal Co-operative, Inc., 59 Sup. Ct. 993 (I939); Electric Bond \& Share Co. v. Securities and Exchange Commission, 303 U. S. 4 I9 (I938). In the Electric Bond \& Share case we stated (see page 442):

"When Congress lays down a valid rule to govern those engaged in transactions in interstate commerce, Congress may deny to those who violate the rule the right to engage

- A.B., r929, Williams College; LL.B., r932, Harvard University. Special Assistant to the Attorney General, United States Department of Justice. Author of That Commerce Which Concerns More States Than One (r934) 47 Harv. L. Rev. 1335 and Separability and Separability Clauses in the Supreme Court (I937) 5 I HaRv. L. REv. 76.

${ }^{3}$ In the first case arising under the commerce clause, United States v. The Brigantine William, Fed. Cas. No. $x 6,700,28$ Fed. Cas. 614 ( 1808 ), District Judge Davis, who was the youngest member of the Massachusetts convention which ratified the Constitution, upheld the embargo on American trade with England and France-the most sweeping prohibition of commerce in our history. 
in such transactions. Champion v. Ames, r88 U. S. 321; United States v. Delaware \& Hudson Co., 213 U.S. 366, 415; Brooks v. United States, 267 U. S. 432, 436, 437; Gooch v. United States, 297 U. S. 124; Kentucky Whip \& Collar Co. v. Illinois Central R. Co., 299 U. S. $334,346,347 . "$

It is contended, however, that the prohibition against interstate shipment of goods made under sub-standard labor conditions regulates production rather than commerce, and that its purpose and necessary effect are to control labor conditions in the state in which the commodity is produced. A similar argument was made in Mulford v. Smith, supra, wherein it was contended that the regulation of the amount of tobacco which could be marketed was intended to and did in fact control the amount which would be produced. We there held that "the motive of Congress in exerting the power is irrelevant to the validity of the legislation."

The regulation of interstate commerce here will have no more direct effect upon production than was true in the Mulford case. That decision and many others indicate that an exercise of federal power is not invalid because of its effect upon transactions which might lie outside the sphere of federal regulation. United States $v$. Carolene Products Co., 304 U. S. I44, I47 (I938); Railroad Retirement Board v. Alton R. R., 295 U.S. 330, 37I (r935); Veazie Bank v. Fenno, 8 Wall. 533, 548 (U. S. I869); McCray v. United States, I95 U. S. 27, 60 (I904); Sonzinsky v. United States, 300 U.S. 506 (I937); cf. Magnano v. Hamilton, 292 U. S. 40 (I934). The Constitution does not state that the power of Congress to regulate commerce may not be exercised if Congress has other motives or purposes than the protection of commerce itself, or because the regulation may have an effect upon intrastate activities.

It is true that Congress may not "under the pretext of executing its powers, pass laws for the accomplishment of objects not intrusted to the government." McCulloch v. Maryland, 4 Wheat. $3^{16,423}$ (U. S. I8rg). Whether prohibition of interstate shipments could ever be deemed a mere "pretext" for the regulation of interstate commerce need not be determined here. 5 Clearly the Fair Labor Standards Act presents no such problem. The purpose of the regulation was to prevent use of the channels of interstate commerce in such a way as to spread low labor standards throughout the country. Section 2 of the statute declares that the existence in the production of goods for commerce of sub-standard labor conditions "causes commerce and the channels and instrumentalities of commerce to be used to spread and perpetuate such labor conditions among the workers of the several states" and "constitutes an unfair method of competition in commerce." Even without any such finding by Congress we could take judicial notice of the fact, as a matter of present-day common knowledge, that producers with sub-standard and harmful labor conditions frequently have an advantage over their competitors in selling goods in interstate commerce, and that it is the use of the channels of interstate commerce by such producers that to a con-

\footnotetext{
4Story, Commentaries on the Constitution (5th ed. 1891) \$\$965, 1079, 1081, ro89.

We will be able to deal with the far-fetched illustrations referred to by appellce, such as the prohibition of the interstate transportation of goods produced by divorced persons, when and if such cases arise. Such statutes would find obstacles in the due process clause.
} 
siderable extent is responsible for the continued and widespread existence of such conditions throughout the nation.

In Mulford v. Smith, supra, we stated:

"... Any rule, such as that embodied in the Act, which is intended to foster, protect and conserve that commerce from working harm to the people of the nation, is within the competence of Congress. Within these limits the exercise of the power, the grant being unlimited in its terms, may lawfully extend to the absolute prohibition of such commerce, and a fortiori to limitation of the amount of a given commodity which may be transported in such commerce."

Thus, even if we assume that an additional connection with interstate commerce -a purpose or effect related to commerce-is essential to the validity of a direct regulation of such commerce, the Fair Labor Standards Act would be valid. The power of Congress to set standards to govern competition in interstate commerce cannot be doubted. That power extends to both interstate and intrastate practices which affect interstate competition. Numerous cases under the Sherman, Clayton and Federal Trade Commission Acts have applied the commerce clause to intrastate transactions which restrain or otherwise affect interstate competition. ${ }^{\circ} A$ fortiori may Congress regulate interstate commerce itself, as it has done here, in order to raise the standards of interstate competition.

We have also held that Congress may prevent goods produced by prison labor from being shipped in interstate commerce because of the effect upon labor standards in the state of destination. Kentucky Whip \& Collar Co. v. Illinois Central R. R., 299 U. S. 334 (I937). Although that case dealt with a statute which supplemented state legislation, the paramount power of Congress over interstate commerce is not limited in scope to the furtherance of state policy. United States v. Hill, 248 U. S. 420 (I9I9); Clark Distilling Co.v. Western Maryland Ry., 242 U. S. $3^{\text {II }}$ (I9I7). The detrimental effects of prison labor are of the same kind as that of child labor or adult labor paid low wages. If Congress may take steps to prevent one, it can take similar action with respect to the others.

Appellee urges upon us the authority of Hammer v. Dagenhart, 247 U. S. 25 I (I9I8), which held unconstitutional a I9I6 statute (39 Stat. 675) prohibiting the interstate transportation of child-made goods. That statute might be distinguished from the present Act on the ground that Congress has here made specific findings, based upon facts of common knowledge, as to the existence of a relationship between the statutory prohibition and interstate commerce. Cf. Hill v. Wallace, 259 U. S. 44 (1922), and Chicago Board of Trade v. Olsen, 262 U. S. I (I923). But we are reluc-

- Northern Securities Co. v. United States, I93 U. S. I97 (r904); Swift \& Co. v. United States, I96 U. S. 375 (1905); United States v. Patten, 226 U. S. 525 (1913); Coronado Coal Co. v. United Mine Workers, 268 U. S. 295 (I925); Van Camp \& Sons v. American Can Co., 278 U. S. 245 (I929); American Can Co. v. Ladoga Canning Co., 44 F. (2d) 763 (C. C. A. 7th, 1930), cert. denied, 282 U. S. 899 (193I); Federal Trade Commission v. Eastman Kodak Co., 7 F. (2d) 994 (C. C. A. 2d, 1925), affd, 274 U. S. 6rg (r927); Chamber of Commerce v. Federal Trade Commission, 13 F. (2d) 673 (C. C. A. 6th, 1926); Temple Anthracite Coal Co. v. Federal Trade Commission, 5I F. (2d) 656 (C. C. A. 3d, I93I). 
tant to hold that such findings are essential to the validity of a law. Cf. United States v. Carolene Products Co., supra. In substance the statute declared unconstitutional in Hammer v. Dagenhart is identical with the child labor provisions in the present Act. And the prohibition against transporting goods produced by adults working under sub-standard conditions cannot be distinguished in theory from the ban upon shipping goods produced by children. For this reason we deem it necessary to consider whether Hammer v. Dagenhart should be followed or overruled.

Four Justices of this Court dissented from that decision. It has been subjected to a barrage of criticism by secondary authorities. ${ }^{7}$ Examination of the majority opinion in the light of subsequent decisions of this Court reveals that each of the basic premises upon which the opinion rests has already been repudiated or abandoned.

The majority in Hammer v. Dagenhart stated that Congress did not have the power to prohibit the interstate movement of "ordinary" or "harmless" commodities (pp. 270-272). A similar contention was held "inadmissible" in Kentucky Whip \& Collar Co.v. Illinois Central R. R., supra, and it is clearly inconsistent with what we said recently in Mulford v. Smith, supra. The Constitution contains no such limitation; to limit the power to prohibit commerce to "harmful commodities" is to read into the Constitution what is not there.

As a corollary to the argument just considered, the opinion suggested that the power to restrict interstate transportation may be exercised only when necessary to avoid "the accomplishment of harmful results" (p. 271), and that the Child Labor Act cannot be deemed to fall within that category. This argument appears to be no more than a restatement of the first; it is clear from the opinion that only "harmful commodities" (such as impure food, lottery tickets, liquor, and women) were considered capable of producing "harmful results." Moreover, the opinion does not find that the use of child labor and dissemination of its effect through the channels of interstate commerce is not an evil, but rather suggests the contrary (p. 275). Thus, even if the premise that the power of Congress is limited to the prevention of "harmful results" be accepted, we cannot say that sub-standard labor conditions or child labor do not produce such results. Cf. Kentucky Whip \& Collar Co. v. Illinois Central R. R., supra.

It was stated in Hammer v. Dagenhart that Congress may not "control interstate commerce" in order to prevent "unfair competition" between manufacturers in states with different standards of labor (p. 273). The Court seemed to be of the opinion

\footnotetext{
${ }^{2}$ See Some Legal Aspects of the National Industrial Recovery Act (x933) 47 HArv. L. Rev. 85, 88; Corwin, Congress's Power to Prohibit Commerce, a Crucial Constitutional Issuc (1933) I 8 CoRN. L. Q. 477, 496; Gordon, The Child Labor Law Case (1918) 32 HARv. L. Rev. 45; Cushman, The National Police Power Under the Commerce Clause of the Constitution (1919) 3 MinN. L. Rev. 452; Powcll, The Child Labor Law, the Tenth Amendment and the Commerce Clause (1918) 3 So. L. Q. 175; Bikle, The Commerce Power and Hammer v. Dagenhart (1919) 67 U. of PA. L. Rev. 21; Note (1918) I7 Mrck. L. Rev. 83. But see Bruce, Interstate Commerce and Child-Labor (1919) 3 MinN, L. Rev. 89; Miller, Federal Regulation of Hours of Labor in Industry (1933) II TENN. L. Rev. 247. 'The articles written before the Court's decision are especially interesting. Sce Brinton, The Constitutionality of the Federal Child Labor Law (1914) 62 U. of PA. L. REv. 487; Lewis, The Fedcral Power 10 Regitlate Child Labor in the Light of Supreme Court Decisions, id. at 504.
} 
that an unfair practice occurring during the course of the production of goods to be shipped into interstate commerce could not be subjected to the commerce power no matter how great its effect upon interstate competition. ${ }^{8}$ This proposition is inconsistent with the many cases cited above, supra, note 6 , as well as with the basic doctrine that Congress may protect interstate commerce against injury "no matter what the source of the dangers which threaten it." Second Employers' Liability Cases, 223 U. S. I, 5 I (Igr2); National Labor Relations Board v. Jones \& Laughlin Steel Corp., 3 or U. S. I, 37 (r937).

Hammer v. Dagenhart declared that "a statute must be judged by its natural and reasonable effect" (p. 275), and that since the prohibition against interstate shipments of child-made goods necessarily affected child labor it was not a regulation of interstate commerce. We have pointed out above that the constitutionality of a regulatory statute is to be determined by what it regulates, not by what it affects.

The opinion further held that the regulation of labor conditions in manufacturing enterprise was a purely local matter falling within the powers reserved to the states under the Tenth Amendment. But conditions of employment are not "purely local"; when they directly affect interstate commerce, they are subject to the regulatory control of Congress. National Labor Relations Board v. Jones \& Laughlin Steel Corp., supra. Nor can it be said that the Tenth Amendment, which reserves to the states only the powers not granted to Congress, imposes any limitation upon the exercise by Congress of its power under the commerce clause. See page 44r, infra.

The effect of the decision in Hammer $v$. Dagenhart was to establish a limitation upon the commerce power which is contained nowhere in the Constitution, and which is contrary to the nature of the grant as defined in cases running from Gibbons v. Ogden, 9 Wheat. I, Ig6 (U. S. I824), to the most recent decisions of this Court. Kentucky Whip \& Collar Co. v. Illinois Central R. R., supra; United States $v$. Carolene Products Co., supra; Currin v. Wallace, supra; United States v. Rock Royal Co-operative, Inc., supra; Mulford v. Smith, supra. Since the states are precluded by the commerce clause itself from prohibiting interstate shipments of goods produced under sub-standard labor conditions, the decision created a no-man's land in which neither State nor Nation could function. The establishment of such a hiatus in governmental power is plainly contrary both to the letter and spirit of the Constitution. Story, Commentaries, Sec. 282; Carter v. Carter Coal Co., 298 U. S. 238, 326 (I936) (dissenting opinion of Mr. Justice Cardozo).

For these reasons Hammer v. Dagenhart must be, and it hereby is overruled.

It is urged that the prohibitions of interstate shipment in Section $I_{5}(\mathrm{a})$ (I) and (4) are auxiliary to and inseparable from Section $I_{5}(a)(2)$. Since these provisions may be independently applied, and since Congress has expressed its intention that invalid parts be excised and the remainder of the Act enforced (Section Ig), we do not regard them as inseparable. Electric Bond \& Share Co. v. Securities \& Exchange

\footnotetext{
${ }^{8}$ It was not suggested that Congress lacked the general power to prevent unfair competition in interstate commerce or that the use of cheap child labor could not be regarded as unfair.
} 
Commission, supra. In any event, since we hold that Section $\mathrm{r}_{5}(\mathrm{a})(2)$ is also valid, the question need not be considered further.

(b) Section $15(a)(2)$. Section 15 (a) (2) presents a somewhat different problem. That clause of the Act does not merely forbid interstate shipments; it makes it unlawful for employers to pay lower wages or require longer hours (without additional compensation) than those permitted under Sections 6 and 7 of the Act. The latter sections protect employees "engaged in commerce or in the production of goods for commerce."

The acts of appellee sought to be penalized under these provisions of the Act are intrastate transactions. But such transactions may be regulated by Congress if they directly affect interstate commerce. As we said in National Labor Relations Board $v$. Jones \& Laughlin Steel Corp., 30I U. S. I, 37, 38, "Although activities may be intrastate in character when separately considered, if they have such a close and substantial relation to interstate commerce that their control is essential or appropriate to protect that commerce from burdens and obstructions, Congress cannot be denied the power to exercise that control.... The close and intimate effect which brings the subject within the reach of federal power may be due to activities in relation to productive industry although the industry when separately viewed is local. ..." In that case and in subsequent decisions ${ }^{2}$ the application of the power of Congress to labor relations in factories similar to appellee's has been repeatedly upheld.

Congress here has found that sub-standard labor conditions lead to labor disputes burdening and obstructing commerce and the free flow of goods in commerce. Section 2. The two most common causes of labor disputes which obstruct commerce are unsatisfactory wages and hours and the refusal of employers to bargain collectively with the freely chosen representatives of their employees. ${ }^{10}$ We have sustained the power of Congress to prevent practices which bring on the second type of labor disputes, when such disputes would obstruct interstate commerce. For the same reason Congress may seek to avoid the other major cause of labor disputes which interfere with commerce.

Congress has also found that sub-standard labor conditions constitute an unfair method of competition in commerce. That an employer who pays lower wages than his rivals has a competitive advantage over them in the sale of his products is an obvious economic fact, which in many industries is not counterbalanced by the superior ability of those higher paid. Interstate sales are likely to be and frequently are diverted to the trader whose employees are paid the lowest wages. Sub-standard labor conditions thus affect interstate competition and the flow of goods in interstate com-

\footnotetext{
- National Labor Relations Board v. Friedman-Harry Marks Clothing Company, 30 r U. S. 58 (1937); Santa Cruz Fruit Packing Co. v. National Labor Relations Board, 303 U. S. 453 (1938); Consolidated Edison Co. v. National Labor Relations Board, 305 U. S. 197 (1938); National Labor Relations Board v. Fainblatt, 59 Sup. Ct. 668 (1939).

${ }^{30}$ Davgherty, Labor Problems in American Industry (1933) 362. This study, which indicates that many more strikes are caused by disputes as to hours and wages than by any other cause, is confirmed by the figures for I9r9-1933 published in United States Department of Labor, (1934) 39 MO. LAB. REV. 75.
} 
merce as greatly as do other practices long deemed subject to congressional proscription as monopolistic or unfair methods of competition. See Note 6, supra. It is for Congress to declare what competitive practices are unfair. As long as such practices have a substantial effect upon commerce, they are subject to the federal commerce power.

What we have said indicates that Section $I_{5}(a)(2)$ and Sections 6 and 7 have a constitutional basis independent of Section $I_{5}(a)(x)$, which prohibits the interstate transportation of goods produced in violation of the former sections. But the former may also be regarded as ancillary and supplementary to the latter. ${ }^{11}$ Congress has the power to control activities which would normally be outside its sphere of regulation in order to make effective a law validly enacted within the granted powers. Thus, in United States v. Ferger, 250 U. S. I99 (1919), a statute penalizing the forging of interstate bills of lading was sustained in order to make legitimate bills more acceptable, although the forgery itself was not connected with any interstate shipment. Prohibition of the sale and manufacture of liquor which is not intoxicating has been sustained where power to prohibit the sale of intoxicating liquor existed, because the legislative body felt that control of non-intoxicating liquor was essential to the effectiveness of the primary prohibition. Ruppert v. Caffey, 25I U. S. 264 (I920); Purity Extract \& Tonic Co. v. Lynch, 226 U. S. I92 (19r2). See also Westfall v. United States, 274 U. S. 256, 259 (I927); St. John v. New York, 201 U. S. 633 (Ig06).

The policy of Congress in this Act was to prevent goods produced under substandard labor conditions from being moved in interstate commerce and thereby affecting interstate competition and labor conditions in other states. The transportation of such goods is in itself made unlawful. But Congress is not required to withhold its hand until the employer has succeeded in starting the goods on their interstate journey. Direct prohibition of sub-standard labor conditions in the production of goods for interstate commerce (not in the production of all goods) plainly tends to effectuate and supplement the policy of keeping such goods out of commerce. We cannot say that Congress exceeded its power by adopting this means of achieving its legitimate goal.

What we have said with respect to the validity of Section $I_{5}(a)(2)$ applies equally to the regulation of wages and of hours, to employees directly engaged in working as machine operators on the goods produced and shipped and to stenographers on the clerical staff. ${ }^{12}$

With respect to the interrelationship of hours and wages Mr. Justice McKenna, concurring, stated in Wilson v. New, 243 U.S. 332 (r9I7):

"The time of service and the price of service may be said to be the reciprocals of each other-each the price of the other. There can be no real estimate of the wages one receives until it is understood what time one has worked to receive them."

11 The existence of such an interrelationship does not imply inseparability.

${ }^{12}$ Section $3(j)$ declares that "an employee shall be deemed to have been engaged in the production of goods if such employee was employed in producing, manufacturing . . or in any other manner working on such goods or in any process or occupation necessary to the production thereof, in any State." 
Here the relationship is clear, for the statute does not impose any absolute limitation upon hours worked, but only requires that one and one-half times the regular rate of pay be given for hours in excess of the maximum.

That clerical employees who do not physically produce the goods to be shipped in commerce are essential to their production and shipment cannot be subject to doubt. A factory could not run for long if its clerical force was on strike. The payment of low wages to a clerk gives a manufacturer selling in interstate commerce just as much of an advantage over his competitors as the payment of similar wages to a factory hand. Their work is an integral part of the process of production. It thus comes within the statutory definition of "production of goods for commerce," and is subject to the commerce power. Cf. Virginian Ry. Co. v. System Federation No. 40,300 U. S. 515,556 (1937).

It is urged, as it has been in other recent cases, that application of the commerce clause to wages and hours in manufacturing enterprises which ship goods into interstate commerce will completely destroy the division of governmental functions in the United States between the States and the Nation. It is claimed that power over all commerce-interstate and intrastate-will be centralized in Congress to the exclusion of the states, and that this was not contemplated by the framers of the Constitution. The growth of the field in which the commerce power may be exercised is a direct and inevitable development of the integration of the national economic structure. Whereas in the eighteenth and early nineteenth century the business of a manufacturer was a local enterprise, today it plainly is not. The commerce clause itself, with its erasure of state lines for purposes of commerce, has been largely responsible for the expansion of commerce along interstate and national lines. The most ignorant businessman knows that competition from other states will prevent any state by itself from requiring that wages be raised in its factories, and that low wages in one state will have a direct and immediate effect upon the flow of goods in interstate commerce from that state and from other states. We suspect that only false tears are shed over the loss by the states of theoretical powers which never have been and never can be effectively exercised. We cannot shut our eyes to what all others can see. If the result is that the field of possible congressional regulation under the commerce clause is enlarged, the cause is not a change in our basic conception as to what the Constitution means, but a recognition of the vast expansion in the number and importance of those intrastate transactions which are economically inseparable from interstate commerce-of the unification along national lines of our economic system. Cf. Stafford v. Wallace, 258 U. S. 495, 518-5I9 (r922). The scope of the federal commerce power must necessarily grow as interstate commerce, unrestrainable by the states, plays an increasingly vital part in the development of the Nation.

Appellant presses upon us the decision in Carter v. Carter Coal Co., 298 U. S. $23^{8}$ (1936), wherein it was held that Congress lacked power to regulate hours and wages or to require collective bargaining in the bituminous coal industry. The majority 
opinion in that case held that labor conditions were incidents of production, and that the power of Congress could not apply to such matters regardless of how "substantial" the effect on interstate commerce. That ruling is inconsistent both with prior ${ }^{\mathbf{1 3}}$ and subsequent ${ }^{14}$ decisions holding that the commerce power extends to all intrastate transactions which directly or substantially affect interstate commerce, even though they occur during the course of production of goods in a factory. The cases under the National Labor Relations Act, which have upheld that Act as applied to labor relations in factories and mines shipping into interstate commerce, indicate that we no longer regard the Carter case as authoritative. Schechter Poultry Corp. v. United States, 295 U. S. 495 (1935), is plainly distinguishable. The labor conditions there subjected to regulation were those of employees in local poultry houses in New York City which sold poultry to retailers in the same city. The effect of the wages and hours of such employees upon interstate commerce is obviously much less direct and substantial than in the case at bar.

\section{The Tenth Amendment}

Appellee's argument that the Act violates the Tenth Amendment is disposed of by our decision that it is an exercise of the power of Congress to regulate interstate commerce. The Tenth Amendment provides only that-

". . . The powers not delegated to the United States by the Constitution, nor prohibited by it to the States, are reserved to the States respectively, or to the people.

Language could not express more clearly the thought that the Amendment does not reserve to the states any part of any power which is "delegated to the United States by the Constitution," nor indicate more plainly that the Amendment does not limit the scope of any power which is delegated to the United States. The Amendment has no independent operation. It comes into effect only after a determination that an Act of Congress is not authorized under the granted powers.

That the Amendment means only what it says is demonstrated by the history of its adoption. The men who sponsored it sought only to remove any doubts that the proposed Constitution gave to the Federal Government any power beyond those enumerated, ${ }^{15}$ and to insure that the states could continue to exercise the powers not granted to the Congress. ${ }^{16}$

The decisions of this Court have reiterated that the Tenth Amendment contains no independent limitation upon the powers granted to the United States but merely states the unquestioned principle that the central government is one of enumerated powers. ${ }^{17}$ Martin v. Hunter's Lessee, I Wheat. 304,325 (U. S. 1816); McCulloch v.

${ }^{13}$ Loewe v. Lawlor, 208 U. S. 274 (1908); Standard Oil Co. v. United States, 221 U. S. I (Igrr); Coronado Coal Co. v. United Mine Workers, 268 U. S. 295 (1925); Bedford Cut Stone Co. v. Journeymen Stone Cutters' Association, 274 U. S. 37, 48 (r927); Standard Oil Co. (Indiana) v. United States, 283 U. S. 163 (I93I).

${ }^{14}$ See National Labor Relations Board v. Jones \& Laughlin Steel Corp., 30r U. S. I and cases cited in note 9 , stupra.

${ }^{28}$ See 2 Euliotr's Debates (2d ed. 1836 ) I23, 124, 13I, I53, I69; 3 id. at 442, 446, 449; 4 id. at I67; and I ANnals of Congress, 44I, 2 id. at I897. ${ }_{18} 3$ Elilotr's Debates, $44 \mathrm{I}, 446,449$.

${ }^{17}$ In 1808 in United States v. The Brigantine William, supra note 3, Judge Davis stated with respect to the Tenth Amendment (p. 622): ". . . The general position is incontestable, that all that 
Maryland, 4 Wheat. $3^{16}$ (U. S. r819); Gordon v. United States, II7 U. S. 697, 705 (1864); Champion v. Ames, I88 U. S. 321, 357 (1903); Northern Securities Co. v. United States, 193 U. S. 197, 344-345 (1904); Everard's Breweries v. Day, 265 U. S. 545, 558 (1924); Missouri v. Holland, 252 U. S. 416, 432 (1920); United States v. Sprague, 282 U. S. 716, 733 (193I); Ashwander v. Tennessee Valley Authority, 297 U. S. 288 (1936); Wright v. Union Central Ins. Co., 304 U. S. 502, 516 (1938).

Appellee calls to our attention language in certain of our more recent opinions ${ }^{18}$ which by implication at least appear to indicate that the Tenth Amendment may have broader scope. We cannot regard anything said in those opinions as impairing a firmly established constitutional doctrine, or as requiring us to give to the Tenth Amendment a construction its words will not permit.

\section{The Fifth AMendment}

The Fifth Amendment provides that no person may be deprived of life, liberty or property without due process of law. The rights thus protected are not absolute. Liberty, including liberty of contract, is subject to restriction by legislative action, for "the liberty safeguarded is liberty in a social organization which requires the protection of law against the evils which menace the health, safety, morals and welfare of the people. Liberty under the Constitution is thus necessarily subject to the restraints of due process, and regulation which is reasonable in relation to its subject and is adopted in the interests of the community is due process." West Coast Hotel Co. $v$. Parrish, 300 U. S. 379, 39I (1937); Chicago B. \& Q. R. R. v. McGuire, 219 U. S. 549, 567 (IgII). Thus, a statute will be held to violate the due process clauses in the Fifth and Fourteenth Amendments only if it bears no reasonable relation to the object sought to be obtained or is arbitrary, capricious or plainly contrary to reason. Nebbia v. New York, 29I U. S. 502 (1934); West Coast Hotel Co. v. Parrish, supra.

(a) The objects sought to be obtained in the Fair Labor Standards Act are the elimination of the evils resulting from sub-standard labor conditions and the prevention of the spread of those evils from one state to another through the channels of interstate commerce. The provisions of the Act are obviously immediately and directly related to the accomplishment of these objects.

Appellee argues that the statute fails in this respect because it bears no reasonable relationship to a legitimate object of federal regulation. The argument merely states in different form the contention that the Act does not come within any of the enumerated powers; it is answered by our holding that the Act is within the power of Congress over interstate commerce. The argument confuses the question of whether there is federal power over the transactions regulated with the entirely separate question of whether a regulation enacted pursuant to the granted powers comports with due process of law.

is not surrendered by the Constitution, is retained. The amendment which expresses this, is for grcater security; but such would have been the true construction, without the amendment."

${ }^{18}$ Hopkins Savings Assn. v. Cleary, 296 U. S. 315 (1935); United States v. Butler, 297 U. S. I (1936); Ashton v. Cameron County District, 298 U. S. 513 (1936); Hammer v. Dagenhart, 247 U. S. 251 (1918). 
(b) It is not suggested that the Act is arbitrary, capricious or unreasonable because of anything intrinsically unfair in its provisions. Nor is it urged upon us that the child labor or maximum hour sections of the Act are invalid as arbitrary or unreasonable infringements upon liberty of contract. That such provisions do not violate the due process clause has been firmly established in cases arising under the Fourteenth Amendment, ${ }^{19}$ and the decision must be the same under the Fifth Amendment when Congress is acting within any of the enumerated powers. United States v. Rock Royal Co-operative, Inc., supra; Nebbia v. New York, supra; Steward Machine Co. v. Davis, 3 or U. S. 548 (r937). The claim is, however, that any law fixing minimum wages for men is necessarily invalid as an arbitrary deprivation of liberty and property without due process of law, and that this statute was not intended merely to apply to women's wages. The latter, of course, is obviously true.

The Fifth Amendment nowhere states that certain types of legislation are inherently invalid, even though not arbitrary or unreasonable in fact, and we refuse to read any such limitation into it. Although this Court did for a time interpret the due process clause as if it contained such a restriction with respect to statutes fixing wages and prices (Adkins v. Childrens' Hospital, 26I U. S. 525 (I923); Tyson \& Bro. ข. Banton, 273 U. S. 4 I8 (I927); Williams v. Standard Oil, 278 U. S. 235 (I929)), that doctrine was recognized as unsound in Nebbia v. New York, supra, and the Adkins case was expressly overruled in West Coast Hotel Co. v. Parrish, supra. Although the Parrish decision upheld a state minimum wage law for women, the principles there approved apply to men as well. ${ }^{20}$ For regardless of the sex of the persons protected, legislation fulfils the requirements of due process if it is not arbitrary or capricious in fact. We cannot say that it is unreasonable for Congress to seek to protect both male and female workers against low wages which impair their health and that of their families, or to safeguard employers against competitors who pay their employees such wages.

For the above reasons, we hold that the District Court erred in holding the Fair Labor Standards Act unconstitutional and in sustaining the demurrer.

\footnotetext{
${ }^{10}$ Holden v. Hardy, I69 U. S. 366 (I898); Muller v. Oregon, 208 U. S. 412 (I908); B. \& O. R. R. v. Interstate Commerce Commission, 221 U. S. 6I2 (I9II); Sturges \& Burn Co. v. Beauchamp, 23I U. S. 320 (rg13); Riley v. Massachusetts, 232 U. S. 67I (IgI4); Bunting v. Oregon, 243 U. S. 426 (1917).

${ }_{30}$ The Parrish opinion contains considerable discussion of the necessity of safeguarding the health of women for the benefit of posterity. As one commentator has stated, "The influence of male workers in this respect can hardly be dismissed as insignificant." (I939) 52 HARv. L. REv. 647.
} 